\title{
RESTORATIVE JUSTICE: BRINGING BACK THE PILLORY?
}

\author{
John $C$ von Bonde \\ BJuris LLB LLD \\ Lecturer in Law \\ Nelson Mandela Metropolitan University \\ Port Elizabeth
}

\section{SUMMARY}

This article considers the value and parameters of re-integrative shaming in the context of restorative justice, particularly in the light of a recent Eastern Cape decision. The basic values and programmes of restorative justice are sketched in order to position this aspect of restorative justice (re-integrative shaming) in the larger milieu. The writer concludes that restorative justice - which is internationally recognised and forms the guiding philosophy in the development of SA criminal justice and sentencing - is multi-facetted. Its strength lies in the fact that it utilises not only existing, but also customary and historical concepts, in order to create fresh solutions to the problem of restoring the harmony in the tripartite relationship of victim/community/offender which is upset when a crime is committed.

\section{$1 \quad$ INTRODUCTION}

In $S v$ Saayman ${ }^{1}$ the meaning of certain aspects of restorative justice was considered. The facts were briefly as follows: the accused, a recidivist with some 203 previous convictions for fraud, was found guilty on six (further) counts of fraud. The magistrate sentenced her to two years imprisonment suspended for five years on condition of her submitting to correctional supervision for a period of 18 months, which included her performing 16 hours per month community service. A further and novel condition of suspension - which formed the basis of the review - required the accused to apologise publicly to the three victims of her crimes by standing in the vestibule of the court for fifteen minutes (under police supervision) bearing a placard with her name and an apology for the harm caused to the victims who were also named on the placard. On review the Eastern Cape Division rescinded this condition on the grounds that it constituted a degrading punishment and was thus in conflict with section 12(1)(e) of the Constitution. ${ }^{2}$ In addition to this finding, which appears to have been the ratio decidendi of the decision, the court found that the form of apology prescribed would not necessarily have involved the cooperation of the victims, there

20081 SACR 393.

The Constitution of the Republic of South Africa, 1996. 
being no certainty that they would even be aware of it. The decision raises the question of the place of apologising to victims and shaming offenders in public within the meaning of restorative justice and the precise dividing line between apology and public shaming.

\section{WHAT IS RESTORATIVE JUSTICE?}

There are many definitions, but Saayman's case ${ }^{3}$ adopts Cormler's definition of restorative justice as quoted with approval in the unreported judgment of Bertelsmann $\mathrm{J}$ in $S \mathrm{v}$ Maluleke: ${ }^{4}$

"Restorative Justice is an approach to justice that focuses on repairing the harm caused by crime while holding the offender responsible for his or her actions, by providing an opportunity for the parties directly affected by the crime - victim(s), offender and community - to identify and address their needs of the aftermath of the crime, and seek a resolution that affords healing, reparation and reintegration, and prevents further harm."

Circumstances - including the political agenda of governments - influence the meanings attached to restorative justice and the parameters of the concept. $^{5}$ The Saayman judgment refers to the concept of "stigmatic shaming" - an example would be a convicted drunken driver being forced to put a bumper sticker to that effect on his or her car - which is employed in the USA, pointing out that this concept would be unacceptable under SA's constitutional dispensation.

Restorative justice promotes the view that crime is a violation of relationships rather than a simple breaking of the law and that the appropriate response should go beyond punishment and encompass putting right the wrong caused to victims and society. ${ }^{7}$ Zehr, a prominent writer on restorative justice, used the following vocabulary in an early article on the subject: Restitution, atonement, community, victim, accountability, victim involvement in outcome, re-integrative shaming, repairing damage and problem solving. ${ }^{8}$ Restorative justice aspires to helping the victim recover from the crime's effects, promoting offender appreciation of the impact of the crime (on the victim and the community), facilitating the making of reparation by the offender to the victim and, generally, repairing the damage caused to the community ${ }^{9}$ - obviously the apology versus public shaming debate is relevant where offender appreciation of the impact of the crime is concerned. In the South African context, the concept of ubuntu - which underpins the Constitution - is synonymous with humaneness, social justice and fairness, the rehabilitation of offenders and the maintenance of law and order, and

Supra 406.

CC83/04, TPD, dated 13 June 2006

Hoyle and Young "Restorative Justice: Assessing the Prospects and Pitfalls" in McConville and Wilson (eds) The Handbook of the Criminal Justice Process (2002) 525 534-535.

Supra 400.

See, eg, one of the initial works on restorative justice, Zehr Changing Lenses (1990).

8 Zehr "Retributive Justice, Restorative Justice" 19854 New Perspectives in Crime and Justice 34.

9 Bowen and Boyack New Zealand Restorative Justice Practice Manual (2000). 
represents the opposite of victimisation, grievous crimes and cruel and inhuman treatment. ${ }^{10}$ In $S v$ Makwanyane Langa $\mathrm{J}$ stated that ubuntu

\begin{abstract}
"recognises a person's status as a human being, entitled to unconditional respect, dignity, value and acceptance from the members of the community such person happens to be part of. It also entails the converse, however. The person has a corresponding duty to give the same respect, dignity, value and acceptance to each member of that community. More importantly, it regulates the exercise of rights by the emphasis it lays on sharing and co-responsibility and the mutual enjoyment of rights by all".
\end{abstract}

There is thus a marked similarity between the values of restorative justice and ubuntu as both emphasise the harmonisation of damaged relationships within the community in a way which is fair to all parties - "fair" not necessarily being synonymous with "lenient".

While the relationship between victim and offender is paramount in the restorative justice equation, the community is also represented as a collective third party to prevent restorative justice from turning into a reformulation of the civil law of delict/tort and the mixture thereof with criminal law. The community fulfils the role of enforcer and co-victim. ${ }^{12}$ Prior to the emergence of restorative justice (in the late $20^{\text {th }}$ century) the prevailing philosophy behind sentencing legislation in countries such as England and the USA required that offenders receive their "just deserts" - thus retribution, with culpability serving as a mitigating or aggravating circumstance (depending on the circumstances), determined sentence. ${ }^{13}$ The rise of the pro-victim movement resulted in legislation which granted victims rights to state-funded compensation, enhanced their rights to restitution and an input in sentencing. It can thus be said that there has been a movement away from individualising the offender to individualising the victim - what can be referred to as the Participatory Model of criminal justice. ${ }^{14}$ However, while the granting of procedural rights giving victims the right to give an input in the sentencing process may be indicative of a restorative justice approach, this is not necessarily the case, as this input can just as well form part of a conventional punitive system. The victim's input can be a positive one, for example where the victim is consulted when an appropriate penalty is determined, or a more passive one, for example, where the victim is the recipient of an apology and/or restitution. A criminal justice system must be assessed as a whole to determine whether it has adopted the principles of

10 S v Makwanyane 19956 BCLR 665 (CC) par [130]-[131], [223]-[227], [237], [307]-[313] and [516].

11 Supra par [224].

12 Walgrave "Extending the Victim Perspective Towards a Systematic Restorative Justice Alternative" in Crawford and Goodey (eds) Integrating a Victim Perspective in Criminal Justice (2000) 253 264-265; and see generally Barnett and Hagel Assessing the Criminal: Restitution, Retribution and the Legal Process (1977).

13 Erez "Integrating a Victim Perspective in Criminal Justice through Victim Impact Statements" in Crawford and Goodey (eds) Integrating a Victim Perspective in Criminal Justice (2000) 165.

14 Sebba "The Individualisation of the Victim: From Positivism to Postmodernism" in Crawford and Goodey (eds) Integrating a Victim Perspective in Criminal Justice (2000) 5563. 
restorative justice..$^{15}$ The transition from the victim movement to restorative justice came about when the focus shifted purely from the rights of victims in conflict with offenders to the broader goal of improving the whole social, personal and juridical position of those victimised, chiefly through constructive interaction between victim and offender. ${ }^{16}$

According to Zehr, ${ }^{17}$ the pillars of restorative justice are; firstly, the harms and needs of victims (and also communities); secondly, the obligations of offenders (and also communities) to put matters right; and, thirdly, the engagement of stakeholders (victims, offenders and communities). "Put right" refers to addressing harms (to victims as well as communities) and addressing causes at personal, interpersonal, environmental and societal levels. ${ }^{18}$

According to Van Ness and Strong, ${ }^{19}$ the values of restorative justice are:

- Encounter: Creation of opportunities for victims, offenders and community members to meet for discussion of the crime and its effects;

- Amends: Expectation that offenders will take steps to repair the harm caused;

- Reintegration: Seeking to restore victims and offenders as responsible members of the community;

- Inclusion: Provision of opportunities for parties with a stake in a specific crime to participate in its resolution.

Programmes identified with restorative justice are classified as follows: ${ }^{20}$

- Victim-offender mediation: This refers to meetings where trained mediators assist victims and offenders to resolve the conflict by conceiving an approach that they deem appropriate in remedying the wrong caused by the crime.

- Conferencing: This refers to victim-offender mediation programmes that include families, community support groups, police, social welfare officials and attorneys.

- Circles: This refers to conferencing between victims and offenders, but including the community in the decision-making process. The community may be represented by criminal justice staff members or anyone in the community concerned about the crime. All participants are given a voice.

- Victim assistance: Victim assistance programmes support victims in recovering from crime and proceeding through the criminal justice system. While some programmes lobby for victims' rights (particularly the

15 Ashworth "Victims' Rights, Defendants' Rights and Criminal Procedure" in Crawford and Goodey (eds) Integrating a Victim Perspective in Criminal Justice (2000) 185192.

16 Walgrave 253

17 Zehr The Little Book of Restorative Justice (2002) 23.

18 Zehr 34.

19 Van Ness and Strong Restoring Justice (2002) 69-125.

20 Restorative Justice Online (June 2006) http://www.restorativejustice.org/ and the sources quoted there. 
rights of victims to have a primary role in the administration of criminal justice), others address the harm suffered by individual victims.

- Ex-offender assistance: These programmes reintegrate offenders into the community, educating them in constructive conflict-resolution skills that replace anti-social behaviour and foster accountability.

- Restitution: Restitution can take the form of both monetary payments and in-kind services rendered to the victim, thus repairing the financial (and perhaps relational) consequences of crime; restitution also has the potential/goal of turning the offender into a productive person.

- Community service: While restitution repairs the harm to the individual, community service repairs the harm to the community, the secondary victim.

It is clear from the foregoing that apology and/or public shaming are not specific, individual values or programmes of restorative justice; they are means which may, in appropriate circumstances, be employed to heal the rift which the crime has created in the tripartite relationship of victim/community/offender. In the Saayman case, the magistrate was aware of this and chose the means of public shaming to involve all three parties ${ }^{21}$ in fact, in refusing leave to appeal, ${ }^{22}$ the regional magistrate stated that the trial magistrate had tried to: "restore the relations between the parties by assisting the accused to tender an apology in public to the complainants". ${ }^{23}$ It is simply the means that he chose and the mode of imposition which were unconstitutional and thus inappropriate. It is submitted, however, that the value of a public apology should not summarily be stigmatised as being shameful, provided always that the dignity of the accused is not violated. A careful reading of the judgment warrants the conclusion that the magistrate's decision was overturned, not primarily because it conflicted with the requirements and objectives of restorative justice, but because it violated the dignity of the accused and was thus unconstitutional. ${ }^{24}$ Punishment invariably carries in itself the seeds of humiliation, but, as pointed out in Saayman: ${ }^{25}$

"Whilst a prison sentence may be a subjectively humiliating and embarrassing experience for an accused it does not, however constitute an impairment of the accused's dignity such as to render it a punishment of a cruel, inhuman or degrading nature. Society accepts that offenders are sent to prison in certain circumstances but appreciates further that once there they are entitled to be treated with dignity."

21 See the quote from the magistrate's judgment on 401 of the judgment.

22 The case being discussed was a review.

23 Supra 396.

24 Though the judgment does become somewhat blurred on this point where it states (14): "In all the circumstances it is regrettable that the regional magistrate missed the opportunity of imposing a condition of suspension which was compatible with restorative justice."

25 Supra 400. 


\section{A DELICATE BALANCE: VICTIM, CRIMINAL AND STATE}

In order to maintain the appropriate balance in the interaction between victim, criminal and state in ensuring justice, Herman ${ }^{26}$ proposes a parallel justice system that combines the strengths of both restorative justice and the traditional retributive approach to criminal justice. ${ }^{27}$ Walgrave and Aertsen also state that restorative justice should be an integral part of the criminal justice system. ${ }^{28}$ Herman's parallel system advocates two separate paths of justice, namely one for victims and one for offenders. Whereas society has traditionally devoted its energies to prosecuting offenders, this approach suggests a parallel set of victim-oriented responses. The response of the South African criminal justice system will determine whether a successful integration takes place that harnesses the strengths of both approaches, or whether restorative justice remains an awkward, added-on aspect of criminal justice. $^{29}$ It is submitted that this will depend to a great extent on the attitude of those involved actively in the criminal justice system and considered decisions such as those in Saayman which will lay down the ground rules.

Burchell $^{30}$ points out that the success of informal reconciliation requires, firstly, the willingness of the parties before the tribunal to become involved in the catharsis of reconciliation, and secondly, their commitment to ascertaining the unembellished truth. In the absence of these preconditions the process of healing will fail. Hoyle and Young aver that the participation of both victim and offender is often not really willingly given as victims participate motivated by feelings of civic duty and offenders do so with an expectation of reduced punishment. ${ }^{31}$ Making an unpopular decision must then be delegated to an independent and qualified tribunal holding the necessary authority. Though there is dissent as to whether the state ought to enforce the restorative outcome, ${ }^{32}$ it is submitted that Marshall is correct when he says that restorative justice "is complementary to criminal justice, not antithetical to it". ${ }^{33}$ Besides, it is difficult to see how the criminal justice system would deal with so-called "victimless crimes", were the entire criminal justice process to be left exclusively to interaction between victim and offender. Might the controlled - and thus constitutional - harnessing of a public shaming aspect not be useful in such cases? After all, if one can apologise to an individual is it not feasible to apologise to the community?

26 In Zehr and Toews Critical Issues in Restorative Justice (2004) 75. See also Easton and Piper Sentencing and Punishment - The Quest for Justice (2005) 158

27 In $S$ v Makwanyane supra 717 par [129], Chaskalson P stated: "Retribution is one of the objects of punishment, but it carries less weight than deterrence."

28 Walgrave and Aertsen "Reintegrative Shaming and Restorative Justice: Interchangeable, Complementary or Different?" 19974 European Journal on Criminal Justice Policy and Research 67.

29 Burchell Principles of Criminal Law 3ed (2005) 7-9.

30 lbid.

31 Hoyle and Young 525-527.

32 Hoyle and Young 527-530.

33 Marshall "Seeking the Whole Justice" ISTD Conference Repairing the Damage: Restorative Justice in Action 20 March 1977 10, quoted in Hoyle and Young 525-528. 
The success of restorative justice thus depends - likewise as in the case of retributive justice - on the exercise of state authority, and care must be brought to bear as this exercise of power is largely unfettered by normal due process safeguards and the protection afforded by human rights norms. ${ }^{34}$ Divorcing restorative justice from the criminal justice system would create an area of practice where the accused loses the protection of due process with its procedural safeguards. Trampling the accused's rights cannot tie in with the lofty ideals of restorative justice. ${ }^{35}$ As Hoyle and Young put it: ${ }^{36}$

"One obvious role of the state - in any functional system - is to provide dueprocess checks and balances on both the process and outcome of the administration of justice."

\section{RESTORATIVE JUSTICE IN THE SA MILIEU}

That SA legal practice will have to solve problems such as that encountered in Saayman and create a harmonious interface between restorative justice and local conditions is inescapable. Restorative justice is firmly rooted in the South African legal system. Before considering the recognition accorded to restorative justice by the South African legal system, it is worth noting that restorative justice is already flourishing in the uniquely South African - informal justice system of community courts. Perceived advantages of community courts are the absence of court fees and legal costs, the existence of victim-friendly processes and the focus on compensation coupled with a respect for established customary values. In addition to community courts sanctioned by local communities, there is the reality of vigilante groups dispensing summary, mob-style justice in urban townships. Both forums deal with criminal matters, sometimes dealing with the most serious of offences if the population does not trust the efficacy of the police. In community courts justice dispensed takes the form of restitution, service to the aggrieved party, reimbursing lost income and medical costs, or the rendering of service to the community with the concomitant element of public apology as encountered in the Saayman case. In rural areas Matgotlas and Chiefs' Courts dispense justice in a way similar to community courts. Restitution is seen to harmonise damaged relationships more effectively than the imposition of punishment, which is perceived as perpetuating permanent rifts between parties who have to live in close proximity with each other. Sometime members of the police and other functionaries in the criminal justice system ${ }^{37}$ assist, acknowledging albeit unofficially - that these forums are more effective in addressing problems occasioned by offending than the conventional criminal justice

\footnotetext{
Ashworth "Some Doubts about Restorative Justice" 19934 Criminal Law Forum 277.

35 Braithwaite "Restorative Justice: Assessing Optimistic and Pessimistic Accounts" in Tony (ed) Crime and Justice: A Review of Research (1999) 101.

36 Hoyle and Young 525-542.

37 Van Niekerk "At the Coalface: The Childline Experience" in Richter, Daws and Higson-Smith Sexual Abuse of Young Children in Southern Africa (2004) 264.
} 
system. $^{38}$ Magistrates in rural areas try to reconcile the customary dispensation with the formal requirements of the legal system. ${ }^{39}$

Turning to the government's stance, South Africa, as a member of the international community, has professed its commitment to restorative justice. When the Economic and Social Council called for comment on the preliminary draft Basic Principles on the Use of Restorative Justice, ${ }^{40}$ South Africa was one of thirty-seven countries commenting. ${ }^{41}$ In 2002 the Group of Experts on Restorative Justice ${ }^{42}$ of the United Nations Commission on Crime Prevention and Criminal Justice ${ }^{43}$ formulated recommendations ${ }^{44}$ concerning restorative justice. On 18 April 2002 the Commission on Crime Prevention and Criminal Justice ${ }^{45}$ recommended to the Economic and Social Council

38 Schärf "Policy Options and Community Justice" in Schärf and Nina The Other Law - Nonstate Ordering in South Africa (2001) 39.

39 Ndima The Law of Commoners and Kings - Narratives of a Rural Transkei Magistrate (2004) 112.

40 Full title: Basic Principles on the Use of Restorative Justice Programmes in Criminal Matters (United Nations) 2000, International Centre for Justice and Reconciliation (April 2002) http://www.restorativejustice.org/rj3/Undocuments/UNDecBasicPrinciplesofRJ.html.

41 International Centre for Justice and Reconciliation April 2002), http://www.restorativejustice. org/rj3/UNBasicPrinciples/countriesthatresponded.htm. SA pointed out, inter alia, that traditional retributive criminal justice systems do not provide the best outcomes in resolving conflicts among victims, offenders and members of the community. Victims, who suffer most from crime, remain unsupported, without receiving effective remedies. Restorative justice measures can lead to satisfaction for the victim and prevent future offending and can produce viable alternatives to short terms of imprisonment and fines. Reference was made to the Truth and Reconciliation Commission, the draft bill (as it then was) on juvenile justice and a pilot project (1996-1997) on family group conferences for child offenders as examples of SA's implementation of the aims of restorative justice. Reference was also made to the work of the SA Law Reform Commission encouraging the incorporation of restorative justice principles into SA law. Support was expressed for the idea of developing an international instrument on restorative justice. SA recommended amendment of the wording in order to place the onus on courts to encourage parties to resort to restorative justice measures; the state should also provide programmes to engender social responsibility in young offenders and to prevent recidivism. The final wording does not directly include SA's suggestions, but reflects the spirit thereof; however, specific reference is made to the fact that the victim must not be coerced into taking part in restorative justice procedures against his or her will. Arguably, the latter suggestion is canvassed in the provision that constant research must be conducted to match restorative justice procedures to changing circumstances. See generally: United Nations Economic and Social Council Commission on Crime Prevention and Criminal Justice 2002 Restorative Justice: Report of the Secretary-General E/CN.15/2002/5 (July 2003) http://www.unodc.org/pdf/crime/commissions/11comm/5e.pdf.

42 Jabu Sishuba of South Africa being one of the seventeen experts.

43 United Nations Economic and Social Council Commission on Crime Prevention and Criminal Justice 2002 Document E/CN.15/2002/5/Add.1 (July 2003) http://www.unodc.org/ $\mathrm{pdf} / \mathrm{crime} / \mathrm{commissions} / 11 \mathrm{comm} / 5$ add1e.pdf

44 The main recommendations were: Research must be conducted and disseminated amongst all Member States and other interested parties; the Basic Principles on the Use of Restorative Justice Programmes in Criminal Matters should be reviewed periodically to take account of developments; Member States should exchange useful information with one another; Member States should provide technical and financial assistance to developing countries in the implementation of restorative justice policies; the widest possible dissemination should be given to the Basic Principles on the Use of Restorative Justice Programmes in Criminal Matters.

45 Eleventh Session - Vienna 16-25 April 2002. United Nations Commission on Crime Prevention and Criminal Justice Report on the eleventh session (16-25 April 2002) (April 2003) http://www.unodc.org/pdf/crime/commissions/11comm/14e.pdf. All documents 
the adoption ${ }^{46}$ of a draft resolution which encourages member states to establish guidelines and standards for restorative justice, with legislative authority where necessary. South Africa is a member of the Commission on Crime Prevention and Criminal Justice. ${ }^{47}$

There is ample evidence of the recognition of restorative justice in domestic South African criminal justice policy:

- Section 155 of the White Paper for Social Welfare ${ }^{48}$ requires that welfare programmes for offenders, victims of crime and their families "must aim at restorative justice by taking into account the victims' perspectives and by involving the community in justice processes, thus promoting reintegration and social cohesion".

- In terms of the Probation Services Act ${ }^{49}$ the Minister of National Health and Welfare may establish programmes dealing with, inter alia, the assessment, care, treatment, support, referral for and provision of mediation in respect of victims of crime, ${ }^{50}$ the compensating of victims of crime $^{51}$ and restorative justice as part of appropriate sentencing and diversion options. ${ }^{52}$ Restorative justice is defined as "the promotion of reconciliation, restitution and responsibility through the involvement of a child, and the child's parents, family members, victims and the communities concerned" ${ }^{5}$

- One of the goals enumerated in the preamble to the Child Justice Bill ${ }^{54}$ is "to entrench the notion of restorative justice in respect of children". Section 2(b)(iii) states an object of the Bill to be "supporting reconciliation by means of a restorative justice response", while section 1 defines restorative justice as "the promotion of reconciliation, restitution and responsibility through the involvement of a child, the child's parent, the child's family members, victims and communities".

- In the Foreword to the Victims' Charter - drawn up in terms of the government initiated Victim Empowerment Programme - the Minister for Justice and Constitutional Development states that the document

relevant to the eleventh session are available at: (July 2003) http://www.unodc.org/unodc/ en/crime_cicp_commission_session_11.html?print=yes.

46 The resolution was adopted on 24 July 2002 (Resolution 12 of 2002) at the $37^{\text {th }}$ plenary meeting of the Economic and Social Council. United Nations Economic and Social Council 2002 Document E/2002/INF/2/Add.2 (July 2003) http://www.ods-dds-ny.un.org/doc/UNDOC /GEN/N02/528/42/PDF/N0252842.pdf?OpenElement.

47 Press release 25 April 2002 United Nations Office on Drugs and Crime (March 2003) http://www.undcp.org/odccp/press_release_2002-04-25_2.html.

48 GN 1108 of 1997. Ministry for Welfare and Population Development (June 2006) http://www.polity.org.za/html/govdocs/white_papers/social971.html?rebookmark=1.

116 of 1991

S $3(d)$.

$\mathrm{S} 3(\mathrm{~h})$.

S $3(I)$.

$\mathrm{S} 1$.

B49 of 2002. 
complies with the spirit of the South African Constitution ${ }^{55}$ and adheres to the tenets of restorative justice.

- The South African Law Reform Commission's Report ${ }^{56}$ on sentencing in criminal cases states that "(a)n ideal system should ... allow victim participation and restorative initiatives".

- Discussion Paper 97 of the South African Law Reform Commission deals with the implementation of a state-funded victim compensation scheme in South Africa. It calls for the implementation of such a system relying, inter alia, on the fact that restorative justice emphasises victim empowerment in the criminal justice process.

Perhaps the most profound and successful manifestation of the principles of restorative justice in South Africa is to be found in the deliberations of the Truth and Reconciliation Commission of which Tutu said: ${ }^{57}$

"Having looked the beast of the past in the eye, having asked and received forgiveness and having made amends, let us shut the door on the past - not

in order to forget it but in order not to allow it to imprison us."

It is through lively debate and the development of the law in decisions such as Saayman's that South Africa will draw on its own experience and indigenous wisdom in order to create its own sentencing regime eminently suited to South Africa's unique needs and simultaneously contribute to the international practice of restorative justice.

\section{CONCLUSION}

In summation - and with reference to the utilisation of the word "pillory" in the title hereof - what is stated above shows that restorative justice does not reinvent the wheel, but advocates a rebalancing thereof in order to heal the rift which crime creates in the tripartite relationship of victim/community/ offender. Restorative justice harnesses existing programmes - and proposes the implementation of programmes for which there is historical precedent - in a fresh way in order to achieve this balance. While to modern sensibilities the pillory is unarguably a macabre relic of a less enlightened era, today's society can benefit by adopting one of its core elements, namely re-integrative shaming ${ }^{58}$ in the development of a flexible, vibrant criminal justice system which remains unswervingly faithful to sound, non-negotiable constitutional values.

55 SA Government Website (December 2004) http://www.doj.gov.za/2004dojsite/policy/vc/ 2004vc.pdf.

56 SA Law Reform Commission Sentencing (A New Sentencing Framework) Project 82 Report (2000) 5-6 (2.7-2.8). Website of the University of the Witwatersrand (April 2003) http://wwwserver.law.wits.ac.za/salc/report/project82.pdf. See Neser "Restorative Justice A New Dimension of Sentencing in SA Courts" 2001 (14) SA Journal of Criminal Justice 46 51.

57 Truth and Reconciliation Commission Final Report Chairperson's Foreword Vol 1 Ch 1 Par 91.

58 Zehr 19854 New Perspectives in Crime and Justice 34. 